\title{
Growth and Security Under Welfare-Corporate Capitalism and Market Socialism
}

\author{
Crescimento e segurança sob o capitalismo \\ corporativo de bem-estar e socialismo de mercado
}

MYRON J. GORDON*

\begin{abstract}
RESUMO: Um sistema capitalista puro possui propriedade privada da riqueza e administração da economia via mercados. Como sistema socialista puro, encarou a propriedade e a administração por uma burocracia. Um oferece crescimento e insegurança, e o outro oferece segurança e estagnação. Na realidade, nem existe nem pode existir por muito tempo. As alternativas viáveis são o capitalismo de bem-estar e o socialismo de mercado. Nos últimos cinquenta anos, a transição do capitalismo do bem-estar para o capitalismo corporativo ocorreu no Ocidente sob a liderança dos EUA. Isso resultou no aumento da insegurança e desigualdade nos países ricos e entre países ricos e pobres. A transição do socialismo burocrático para o socialismo de mercado na China nos últimos vinte anos trouxe ao seu povo crescimento e prosperidade surpreendentes - e muitos dos males de uma economia de mercado. Resta ver se o socialismo de mercado na China é uma alternativa atraente ao capitalismo de bem-estar, ou não é mais que uma transição para o capitalismo corporativo. PALAVRAS-CHAVE: Estudos comparados de sistemas econômicos; crescimento econômico; bem-estar social.
\end{abstract}

ABSTRACT: A pure capitalist system has private ownership of wealth and administration of the economy via markets. As pure socialist system has stare ownership and administration by a bureaucracy. One offers growth and insecurity, and the other offers security and stagnation. In reality, neither has existed nor can exist for long. The feasible alternatives are welfare capitalism and market socialism. Over the last fifty years, the transition from welfare to corporate capitalism has taken place in the West under U. S. leadership. It has resulted in increasing insecurity and inequality within rich countries and between rich and poor countries. The transition from bureaucratic to market socialism in China over the last twenty years has brought to its people amazing growth and prosperity- and many of the ills of a market economy. It remains to be seen whether market socialism in China is an attractive alternative to welfare capitalism, or is no more than a transition to corporate capitalism. KEYWORDS: Comparative analysis of economic systems; economic growth; welfare. JEL Classification: P51.

\footnotetext{
* Professor of Finance, Rotman School of Management, University of Toronto, Toronto Canada. E-mail gordon@mgmt.utoronto.ca; gordon@rotman.utoronto.ca.
} 
The two things that people want most from their country's economic system are growth in their income and security in their income. To the degree that workers find security in capitalist co un tries, it has been obtained in large measure, but not solely through social security - old age pensions, unemployment compensation and other benefits, financed through the tax system and managed through government. Social security contrasts with private capitalist arrangement for security portfolio wealth. A third source of security is the corporation. Pensions and other benefits provided by the corporation have grown relative to social security over the last 25 years.

In socialist countries, the government guarantees economic security to its workers, but it delegates immediate responsibility for the security of their income and other benefits to the enterprise or other work unit. Now, it is proposed that the immediate responsibility for pensions and other benefits be transferred to government. To arrive at policy with regard to social security under each type of system, it is useful to understand how security is provided in general and to understand the trade-off between security and growth.

This paper will review the historical development and examine the main current features of welfare-corporate capitalism and market socialism in providing growth and security. Welfare-corporate capitalism and market socialism are the systems that we now enjoy or suffer depending on your point of view, and variations on them are what the future is likely to bring. Our understanding of these two systems is served by first considering four other economic systems. Two are the theories of a pure capitalist system and a pure socialist system. The other two are the actual performances of pure capitalist and pure socialist systems. Our examination of market socialism will rely on China, for the obvious reason that China is the country where market socialism has the longest history and richest development. The two main distinguishing features of a pure capitalist system are a) private ownership of the means of production, and b) reliance on markets for the administration of the economy. By contrast, a pure socialist system has a) public owner ship of the means of production, and b) reliance on a bureaucracy to administer the economy. Neoclassical, that is establishment economists, have constructed a theory of a perfectly competitive capitalist system that is a utopia. Everyone is free to buy, produce and work at whatever she wants. Ali wage and profit rates are fair. There is no unemployment, insecurity etc. Similarly, utopian socialists, anarchists and Marxists in the capitalist world, and establishment socialist economists in the former Soviet Union have constructed various theories of a pure socialist system that also are utopian in nature.

Establishment economists here and in the former Soviet Union have recognized that the real world falls short of their respective utopias. Neoclassical economists tell us that the gap is due to market imperfections. In doing so some of them offer us a more attractive vision of the future than the great theologians. The latter, with few exceptions, recognize that human imperfections make a heaven on earth practically impossible, but some neoclassical economists assure us that heaven on earth requires only that we overcome market imperfections. I presume that the establish- 
ment economists in the former Soviet Union claimed that their utopia required only that imperfections in the bureaucracy be overcome.

In fact, neither pure system has existed in practice for any length of time, and neither is a viable option for the future. Each pure system soon proves to be closer to a hell than a heaven on earth. The worldly function of pure systems is largely ideological. The human desire for perfection makes it attractive for the champions of capitalism to compare the theory of a pure capitalist system with the reality of pure socialist systems in order to reject socialism, while socialist radicals compare the theory of a pure socialist system with the reality of pure capitalist systems in order to justify the call for the end to capitalism. To see why neither pure system is a viable option for the future, and to understand what options we really have, we must look at each of these systems within the context of their historical development.

However, the rationale for the above conclusions that will be presented in what follows can be summarized quite briefly. A pure capitalist system at best provides growth without security, while a pure socialist system at best provides security without growth. People require both security and growth, so that either extreme is intolerable for any length of time. Welfare-corporate capitalism and market socialism can be more or less successful in providing both, so that the survival of each in any country may depend solely on a variety of circumstances surrounding its existence at a particular time and place. There is, however, a difference between the two systems. The dominant, if not the sole distinguishing feature is the ownership and control of wealth. In one, the private ownership of wealth is predominant, while in the other it is collective or public ownership. Perhaps, the private ownership tips the balance between growth and security in favour of growth, while the dominance of public ownership and control has the opposite effect. Whether or not that is true, and if it is true, whether it makes one system more or less attractive and more or less successful in the competition between the two are questions of considerable interest and importance.

\section{TRANSITION FROM FEUDALISM TO CAPITALISM}

European capitalism had its origins in feudal society. Feudalism there arose in the centuries following the fall of the Roman Empire, in order to provide security against the raids of marauding tribes. Tribalism was the alternative economic system at the time. The typical feudal manor was a closed system that also provided economic security through its technology of production and social arrangements. However, the agricultural surplus that increased with the progress of feudal society could not be realized very effectively by employing artisans in the feudal manor for the production of the wide range of manufactures, including armaments and ornaments, that were being produced in the towns. A far more profitable use of this surplus was its sale to the towns, that is by becoming involved in market transactions and the rise of capitalism. Nowhere is the contradiction in the development of a system more vivid than the role of capitalism in the development of feudalism. 
The towns made possible the realization of the surplus being produced on the feudal estates, but they did not merely embellish feudal life by providing it with more attractive products for consumption. The size of the feudal armies, the period of time that they could be mobilized for war, and the quality of their armaments all depended on the development of the towns and their activities. Where the towns were suppressed or failed to develop for other reasons, feudal power stagnated and became vulnerable to defeat.

The towns, however, financed the rise of national monarchs and eventually nation states; so that the progress of feudal society undermined its foundations. The contradictions in this process transformed, corrupted and ultimately destroyed feudal society. It culminated in the transition to capitalism between the $15^{\text {th }}$ and $18^{\text {th }}$ centuries, a unique and remarkable event, since that transition did not take place under roughly similar circumstances in other places ${ }^{1}$ One striking example is $17^{\text {th }}$. century China.

Capitalism can be a very effective engine of economic growth, but it is also a terrible engine of economic insecurity, and without high growth the insecurity is intolerable. This insecurity was moderated during the transition from feudalism to capitalism, both by the growth made possible by the transition, and by the cushion provided by the underlying feudal society. That transition was completed in Great Britain by about 1850 , and by that date the country was to come as dose as it ever was to having a pure competitive capitalist system. Feudalism was gone and the welfare state had not been established. About 1850, Charles Dickens's novels and Karl Marx's Capital, each in its own way, described the consequences of that system for the mass of the people. Marx drew his information from the reports of parliamentary committees on child labor, the employment of women, and the housing and health of the people. These reports warned that unless drastic corrective action was taken, the British working class would be physically destroyed by the competitive capitalist system that was in place.

\section{THE RISE OF WELFARE CAPITALISM}

Over the years 1850 to 1950 , the leading capitalist countries suffered both the privation and insecurity of fluctuations in employment and output, and periodic wars of increasing scale. However, the dominant story was the rise of the welfare state, the extraordinary growth in productivity and in prosperity for both capitalist and worker, and the phenomenal growth in the managerial and professional middle class. The private arrangements to find economic security proved to be inadequate, and social security was found in numerous ways, including trade unions, pension plans, unemployment compensation, socialized medicine and public hous-

\footnotetext{
${ }^{1}$ This evolution and its theoretical framework are presented in greater detail in the last chapter of Gordon (1994).
} 
ing. Progressive taxation and employment expenditure policies, undertaken to increase aggregate demand, were among the other features of the welfare state. With corporate income taxed at rates of about $50 \%$, with marginal tax rates on personal income in excess of $50 \%$, and with the proceeds employed for social welfare, it may have appeared to many capitalists that the peaceful transition to socialism was all but complete. However, the rise in the welfare state is understood better as a Marxist contradiction in the development of capitalism. With the end of feudalism at home, the growth made possible by its elimination and the security provided by its continued existence had to be replaced. Technological progress and imperialism provided continued growth, but that was not enough: the continued development of capitalism required its gradual elimination. Social democracy seemed to be no less effective an instrument for expropriation than socialism.

During the Great Depression, the establishment economic rationale for the welfare state and its related developments were explained with greater rigour and authority than ever before by John M. Keynes and M. Kalecki. The formal recognition and adoption of the welfare state, due in large measure to Keynes, made the years 1945 to 1970 a golden age in capitalist development. It was a period of stability and growth, rising expectations and their realization, at least in the industrialized countries.

\section{CORPORATE CAPITALISM}

The 1970's, however, inaugurated a reversal in the rise of the welfare state, that was due in large measure to the development of the modem corporation over the prior 100 years.

The $18^{\text {th }}$ and $19^{\text {th }}$ centuries manufacturing enterprises described by Adam Smith and Karl Marx were engaged predominantly if not solely in production. Competition was dealt with by means of price wars, mergers and cartels, instruments that did not require a large corporate bureaucracy. Typically, factory and office were located in the same or in adjoining buildings, and managing one or more other factories elsewhere in the same country was a challenging task. Over the last century the progress in travel, transportation, communication, data processing and in the practice of management have resulted in the global corporation. It participates in all of the world's important markets, while moving production almost at will from one low wage country to another in order to minimize production cost.

The distinguishing feature of the modem corporation is that it engages primarily in a wide range of non-production activities in pursuit of monopoly power. These activities include research and development for the purpose of improving existing products, discovering new products and reducing production costs. They include selling and advertising to differentiate products, thereby increasing sales and increasing the mark up of price over production costs. They include labor relations to persuade or intimidate workers to produce more or accept lower wages. They include political contributions, lobbying and corruption of government offi- 
cials in order to obtain natural resources on favourable terms and other favours of government. They include the employment of lawyers, accountants and financiers to avoid and evade taxes and to influence tax legislation. I could go on. These activities may be harmless apart from their cost and their consequences for the distribution of income. They may also be beneficial or malignant in their immediate consequences for society. Regardless, what they all have in common is the pursuit of the profits to be gained from monopoly power. ${ }^{2}$

A useful measure of a firm's monopoly power, called the degree of monopoly, is the ratio of value added to the wages of production workers. Value added is sales volume, less the cost of the materials used in production. The Annual Survey of Manufactures of the U. S. Bureau of Census collects this data. Over the years 1899 to 1949 , the degree of monopoly power in the manufacturing sector of the US economy fluctuated in a narrow range around 2.5. Over the years 1949 to 1994, it rose dramatically to 5.2 , so that production cost accounted for only 20 c of every dollar of profit in 1994. Profit on capital and the cost of monopoly activities absorbed the other eighty cents. The process is simple: corporate growth takes place to the degree that expenditure in the pursuit of monopoly power generates a rise in monopoly power, and the increased profits that result provide the funds for a further rise in the expenditure for monopoly power.

The importance of these monopoly activities is illustrated quite dramatically by looking at the financial statements of Microsoft, a leading high technology company. In the year ending June 1997 it had sales revenue of $\$ 11,358$ million, while the labor and material cost of producing the products sold was only $\$ 1,085$ million. The cost of research and development was $\$ 1,925$ million, while sales and marketing expenses were almost $50 \%$ greater at $\$ 2,856$ million. General and administration expenses came to $\$ 362$ million, and income before deducting income taxes was $\$ 5,314$ million. Notice that the total labor and material cost of producing the output sold during the year was less than $10 \%$ of the value of the goods sold, while the expenditures to maintain and increase its monopoly power came to $45 \%$ of sales revenue, and profits amounted to $47 \%$ of sales revenue. The profit of over $\$ 5$ billion was earned with an investment in inventory, equipment and buildings of less than $\$ 2.0$ billion. The market value of Microsoft's common stock was over $\$ 160$ billion, reflecting the extraordinary opportunities for profitable growth created by its monopoly power. Microsoft is only a somewhat extreme example of the costs incurred and the profits generated in the pursuit of monopoly power by the large modern corporation.

\footnotetext{
${ }^{2}$ The pursuit of monopoly power and its rise in the U. S. manufacturing sector are described in greater detail in Gordon (1998). Schumpeter (1942) in large measure anticipated these developments. Competition takes form of the search for monopoly power that also involves according to Schumpeter the process of "creative destruction" that results in the elimination of monopoly power. The development of the modern corporation is recognized and interpreted in different ways in Chandler $(1977 ; 1990)$, Galbraith (1967), Sherer and Ross (1990), Simon (1976) and Williamson (1985).
} 


\section{WELFARE-CORPORTE CAPITALISM}

Individually and collectively, General Electric, Disney, Merck, Sony, Toyota, Intel, Siemens and all of the other great multinational corporations of the world are magnificent institutions. No less marvelous and accomplishment are the countless small growth enterprises that spring up in response to every opportunity for profit. Most disappear in bankruptcy, many are absorbed by and reinvigorate the great corporations, while a few grow into mighty corporations themselves.

The genius of corporate capitalism is illustrated most vividly by its ability to discover or create opportunities for profit beyond the traditional areas where the market has ruled. The authority and role of government and the threat to corporate power that it represents are thereby being reduced drastically. Government ownership or regulation had been the rule in electricity, telecommunications and other services that are provided by public utility companies, on the grounds that they are natural monopolies, and the public interest is served through the widest possible access. These industries are now being privatized and deregulated with the claim that efficiency and progress are served through the rule of the market. ${ }^{3}$ Concentration of ownership in a few multi-national corporations is not considered a problem. Similarly, health care, education, prisons and other services for which externalities and important public purposes have justified reliance on government or non-profit institutions are now being privatized and made profitable.

Most remarkable has been the transformation of television, newspapers, and book publishing, music, sports, and all other expressions of art and culture. They are being transformed into great industries dominated by multinational corporations such as Disney and Time Warner and extreme right-wing individuals such as Rupert Murdoch and Conrad Black. These new growth industries offer dazzling prospects for profitability. In addition, they convert capitalist control of society from a costly and sometimes ugly burden (Chile, Nicaragua, Angola) to a highly profitable growth industry. For the most recent developments in the corporate control of agriculture and its threat to the survival of peasants in the third world, see Kahn (1999).

The most brilliant and mystifying consequences of the technological and institutional developments that have given rise to corporate capitalism is the internationalization of financial capital. Money, bonds, shares and other forms of nominal wealth now move from one country to another with the speed of light, at practically no cost, in enormous volumes, and beyond the knowledge and control of government. That combined with the World Bank, the IMF, the World Trade Organization and the unchallenged leadership of the United States has reduced drastically the power of

\footnotetext{
${ }^{3} \ln$ the telecommunication and electricity industries, profitability is increased by raising the price for basic services, in particular access to the service, since the demand for access is price inelastic. In addition, basic services are exploited to subsidize exotic services to the rich for which demand is price elastic. Analogous exploitation of the price system takes place in health care and education. Inequality of income and marginalization of the poor, by reducing their access to these services, is thereby increased.
} 
governments relative to corporations. Felix (1998) describes how the international mobility of financial capital is making increasingly difficult the national use of fiscal policy, monetary policy or industrial policy to influence economic performance. Tax avoidance, tax evasion, tax havens and investment incentives are making personal and corporate profits free of taxation. Even the World Bank and the IMF are now raising questions about the international mobility of capital.

Unfortunately, that is not the whole story. The leading capitalist countries have experienced varying combinations of high unemployment rates, high inflation rates, unprecedented government deficits, and increasing inequality and insecurity of income. Now more than ever, the rich get richer and the poor get poorer. See Barnet and Cavanagh (1994), Danzinger and Gottschalk (1995), Gordon (1996), Harrison (1994), Korten (1995) Mishel and Bernstein (1993) and Rifkin (1995). All but a few of the third world countries at the end of World War II have experienced the same ills with even greater force, particularly in Africa and Latin America. In a number of African countries, the breakdown of civil society makes genocide a reality or a likely prospect. In practically all of the other third world countries foreign investment and loans to corporations and governments is a necessary but frequently not a sufficient condition for development. Even when development takes place, a large fraction of the money is diverted to the U. S. dollar accounts of generals, politicians and capitalists. When questions are raised as to how well the money has been used, capital flight forces terrible hardships on the mass of the population, as has taken place in Mexico, Indonesia, Russia and other countries. The flight of money from developed (Japan, Canada, and Western Europe) as well as developing countries to the United States, the depreciation of their currencies and the buying of their industries at fire sale prices is a new form of imperial tribute ${ }^{4}$.

The system we now live in may be called welfare-corporate capitalism. However, the role of the state in providing for the welfare of the population has gradually diminished over the last 25 years, while the role of the corporation in generating growth, monopoly profits, inequality and unemployment has expanded. It is to be hoped that this process is cyclical and not secular, and a desirable balance between the two forces can be achieved. Recent election results in the leading capital-

\footnotetext{
${ }^{4}$ Over the last decade there has been a more or less steady rise in the United States Trade deficit. Among the reasons for that deficit has been the flight of money from the rest of the world, first for the safety and then for the profitability as well of holding U.S. dollar assets, particularly shares of stock. In 1996 before the collapse of the Asian Tigers, the deficit had reached a high of \$195 billion. The preliminary figure for 1997 is $\$ 264$ billion. (See the Survey of Current Business, May 1998). As the currencies of the rest of the world depreciate in response to this flight, more and more of their resources and cheap labor must be exported to earn a dollar. The private wisdom and the national folly of this flight to the dollar is confirmed by the soaring U.S. stock market, and the decline - collapse, in some cases - of the foreign economies. In addition, foreign multinationals recognize that they must have a large presence in the U.S., one that can only be satisfied by acquisitions such as the acquisition of Chrysler by DaimlerBenz of Germany. To the extent that Chrysler shareholders want to keep their money in U.S. shares, the rise in the U.S. stock market and U.S. dollar are both accelerated. See Felix (1998).
} 
ist countries suggest that is what the people want, and it is to be hoped that the democratic process can overcome the increasing corporate influence on the media, the universities and the other means by which corporations control society. The only force capable of destroying capitalism is capitalism itself, and the international capital movements described above make that a real possibility.

\section{BUREAUCRATIC SOCIALISM}

Let us now consider the historical development of market socialism in China, the place where it has achieved its greatest development to date. For over 100 years prior to 1949, when a socialist government came to power in China, rule by imperialist foreign governments and provincial warlords had reduced the country to a state of poverty, corruption, violence and degradation that defied description. Over the next five years, the new government moved rapidly towards a pure socialist system. Ownership of practically all wealth was transferred to the government, and a bureaucracy determined the production and distribution of output. These changes accomplished wonders in terms of equality of income, full employment, and improvements in education, health care and other services. Production of basic commodities such as grain, cloth and steel also increased significantly.

However, the progress that took place under this centralized bureaucratic system made further progress increasingly more difficult. A modern economy requires hundreds, no, thousands of different types of steel, and even greater variety in cloth, food, and other classes of products. Growth and technological progress required change. A central bureaucracy could not possibly acquire all of the information needed to administer the economy effectively. This was particularly true under the primitive state of Chinese technology in travel, communication, data processing and enterprise management. It also could not bring about a high rate of technological progress, since central control required that workers and managers do only what they were told to do: the freedom and motivation to improve, innovate, or work harder would disrupt the system. The Great Leap Forward and the Cultural Revolution were disastrous attempts to catch up with the West within the framework of a pure socialist system.

ln 1978 China decided to expand the role of the market in administering the economy without giving up government ownership. It also decided to acquire technology and to some degree capital from the West through joint ventures, wholly owned foreign companies, private enterprise, and by 'opening to the outside world' in other ways. What were the consequences of this decision?

\section{MARKET SOCIALISM IN THE COUNTRYSIDE}

In agriculture the household responsibility system was adopted. Under it the use of the land but not its ownership was distributed among the peasant households 
in a remarkably egalitarian and equitable manner. Each household was then required to make deliveries to the state in kind or in cash, and beyond that the household could produce what it wished for market and enjoy the proceeds therefrom. Maintaining state ownership made it impossible to separate a peasant family from the income from its plot of land, so that the most populous system of social security in the world was thereby created. Combining the security of state ownership with the material incentives of the market produced spectacular results. Prior to 1978 the growth rate in agricultural production was about $2.1 \%$, little more than the population growth rate. Since then, the growth rate has been over $6.0 \%$, and now all but a small fraction of the Chinese people eats well. The high rate of 'hidden unemployment' that existed in the countryside made it possible to achieve this increased growth rate in agricultural output, the growth in rural industry to be described shortly, and a large migration from the countryside to the cities. Prior to the eighties migration to the cities was prohibited in order to prevent the runaway urban population growth in other third world countries. Now peasants are free to go to the city: they go seasonally or stay if they make out and return to their plot of land if they don't. This freedom is of immense value, material as well as non-material.

Increasingly over the last decade and more so in the future, productivity growth in agriculture will require more technology, a rising capital-labor ratio and better trained farmers. These developments make small scale family farming increasingly inefficient, and the lure of non-farm employment makes staying on the land increasingly unattractive. Hence, an increasing fraction of peasant households are leasing their plots to professional farmers. What this will do to the social security system represented by the socialized collective ownership and democratic sharing in the income from the land remains to be seen. The modernization of agriculture and of industry in the countryside must take place, and that may prove to be a more serious threat than corruption to the survival of market socialism in the countryside.

\section{TOWNSHIP AND VILLAGE ENTERPRISES}

More spectacular than the improvement in agriculture has been the growth of nonfarm employment in the countryside. Prior to the eighties, the low rate of growth in farm output, the high infrastructure investment required to expand urban industry, and the low productivity of urban industry made it unprofitable to expand urban industry at a higher rate than the natural growth rate in the urban population. The inputs would exceed the outputs. Consequently, industry was brought to the countryside, where hidden unemployment and the housing along with other infrastructure assets, made the marginal cost of increased unemployment in nonfarm activities close to zero. Anything earned by the family members that went to work in the township and village enterprises (TVEs) was an addition to family income, and any TVE profit was a net addition to township and village (TV) in- 
come. Another factor in the growth of TVEs was the change in the nature of their output. Prior to 1980 they were engaged largely in the manufacture of agricultural inputs - e.g. tools for farming and fertilizer - in order to maximize self-sufficiency in the countryside. After 1980, the growth in TVEs was mainly in light industry, where the production of consumer goods contributed significantly to exports and the standard of living in China.

Employment in TVEs rose from 28 million in 1978 to 135 million in 1996.

Gross output value, not value added, rose from $32.5 \%$ of the figure for urban stare enterprises in 1984 to $138 \%$ in 1996 . The quality and quantity of the output have improved correspondingly. In bringing industry to the countryside Deng Xiaoping succeeded where Mahatma Gandhi and Mao Zedong failed. With about 200 million peasant households in the countryside, about one in two now have income from the land plus income from TVE employment. The increased prosperity of the peasant families near the big cities and along the coastal plain has been stunning. They now have little material incentive to go to the cities in search of employment. Peasants in the interior with little access to TVE are now free to go to the city for seasonal or permanent employment, so they also share somewhat in the increased prosperity. ${ }^{5}$

In most TV's there is still comparatively little inequality of income and democratic control over local officials remains strong. See Ho (1994), Rozelle (1994), Findlay, Watson, and Wu (1994), and Byrd and Qingsong (1990). However, the expanded role of the market and the relaxation of central control have contributed to increased inequality of income. See Griffin and Zhao (1993), World Bank (1997), and Kahn and Riskin (1998). Furthermore, it is now also possible for the officials and managers in TVs to capture the income and power of landlords and small merchants in third world capitalist countries. In Guangdong, the province that serves as Hong Kong's workshop, severe sweatshop conditions have become a serious problem. In some TVs growth has been so great as to require the employment of peasants from the interior. Since they don't enjoy the same rights as 'citizens ' of the TV, they can be and are exploited more easily. In addition, local officials and Hong Kong capitalists conspire to capture and transfer to Hong Kong a large fraction of the value added in TVEs, so that the foreign exchange enterprises generate for China 's economic development is reduced materially. The story with regard to technology transfer is mixed, in that China has acquired the capacity to manufacture a wide range of low technology but modern consumer products that are useful to the country, while progress in the capacity to innovate and to market abroad comes much more slowly.

The problems for market socialism raised by the modernization of agriculture

\footnotetext{
${ }^{5}$ Poverty imposes hard choices. Prior to the 1990's, peasants were not allowed to go to the cities. That avoided the terrible urban slums, with their vices, child labor, etc., that are found elsewhere. But if you were born a peasant, you knew that you would die a peasant, unless you were lucky. Now peasants are free to go to the city, where they may find prosperity, sometimes by participating in its vices. However, those who don't succeed can return to their farm in the countryside.
} 
are also being encountered with TVEs. Regardless of whether these enterprises are privately or collectively owned, the people who manage them, the TV officials, the TV employees and the TV as a whole, share in the profits and in the control of the enterprises in varying degrees. In fact, ownership is commonly far from clear, and for various reasons it has not been necessary nor desirable to resolve the ownership question. However, as the comparative advantage of small-scale production with low labor and infrastructure costs declines, the TVEs will require increasingly sophisticated technology and a rising ratio of capital (including human capital) to production labor. Whether or not these developments are compatible with continued local ownership and control of enterprises remains to be seen. The passage of time will also create increasing pressure for the clarification of ownership rights in the TVEs. In the West, the appearance of the term 'stakeholder' reflects the increasing complexity of ownership rights under a system of welfare-corporate capitalism. But that is nothing compared to the problem of ownership in the transition from a pure socialist to a market-socialist system. As long as everyone is making money, clarification and finalization of the laws governing the process does not have the highest priority.

\section{CHINA'S STATE ENTERPRISES}

The modernization of China's economy depends critically on the performance of its urban state enterprises, and progress there has been far less impressive than in agriculture and in TVEs. Technology in 1980 in practically every industry was 25 to 50 years behind the West. An enormous range of products introduced and made popular in the West over the prior 25 years were still not produced in China. Practically every industry, therefore, required 1 ) new equipment that could only be imported, 2) the recruitment of an engineering staff with the training needed to use the equipment, 3) advice for staff and workers on how to use the equipment in producing the range of products for which it was designed, 4) foreign exchange to buy the equipment, and 5) foreign enterprises able and willing to provide the equipment and the advice. Perhaps an even greater barrier to the desired technology transfer was the institutional structure of Chinese industry. Socialist principles of equality and stability were strongly entrenched in the state enterprises and in the government bureaucracy. The spread in compensation rates between unskilled workers and enterprise managers was extremely narrow, and all workers shared in generous benefits, that included free education and ealth care, practically free housing and utilities, subsidized food and retirement at $80 \%$ or more of pre-retirement pay. The prime responsibility of management in these state enterprises was to maintain this privileged status for the enterprise and its employees. The term 'iron rice bowl' accurately described the security and mentality in state enterprises.

Over the next 15 years a series of reforms were adopted in order to make enterprises more market oriented and there by overcome the above institutional barriers to improving their technology and productivity. Initially the enterprises 
were allowed to produce for market after satisfying the production plan and keep the profits for investment. Gradually over time production plans determined by the state were abandoned, enterprises bought materials and sold output on the market, kept profits after taxes, and management shared in good performance. However, unprofitable enterprises and their workers could attribute their difficulties to an irrational price structure and other conditions beyond their control. They were subsidized through loans that governments required the banks to make, and through purchase of their output, so that they were not forced to fire unneeded workers or go bankrupt.

The formidable obstacles to modernization and market orientation made one half of the state enterprises by number unprofitable. However, the profitable ones have been profitable enough so that the industrial sector has been reasonably profitable in aggregate, and aggregate output has grown at an annual rate of about $8 \%$ over the last 15 years. It should be added that unprofitability has been largely concentrated in certain industries, coal, oil, textile and heavy machinery in particular, where new technology has not been introduced or product prices have been depressed by government policy to encourage growth and exports. See Gordon, Li and Tian (1998, pp. 255-75).

It is quite remarkable that about half of the state enterprises by number and much more than half in terms of value added have been able to overcome obsolete technology, poor management, an excessive work force and high compensation rates, so that the manufacturing sector in aggregate has been reasonably profitable. Over the last decade the government has experimented with various new ways to deal with the unprofitable enterprises, among them the forced merger of small ones with large successful ones, forced because redundant workers and managers are still not dis missed easily, and neither party welcomes the merger. An increasingly common practice has been to make surplus workers stay at home at reduced pay but with housing and other benefits. Sooner or later many find other jobs, so that hidden unemployment falls, while open unemployment, which excludes peasants who can return to the countryside, did not for a long time climb above three percent of the urban population. ${ }^{6}$

Unemployment in China is a difficult and content io us subject. Prior to the economic reforms, there was no open unemployment such as exists in the West. It was then claimed that there was 'hidden' unemployment, in that $30 \%$ or more of the people employed on the farms and in the cities could be removed without reduc-

\footnotetext{
${ }^{6}$ There is another solution when the loss enterprise has been located on a choice piece of urban land due to the absence of a rational real estate marker. The land is sold for what is worth, and the proceeds are distributed among the former employees. Enterprise debt here as in other liquidations is for the most part cancelled. When the Tianjin Bohai Brewery was declared bankrupt in 1994 with debts of 183 million yuan, its assets were sold for 54 million yuan. Of that amount, 16 million yuan were devoted to retraining programs and separation pay for the workers equal to 3 times annual earnings. An increasing fraction of bank debt becomes unsupported by sound loans, but bank debt is really government debt, which in total is not large relative to GNP.
} 
ing output. Now peasants come to the ci ty looking for work when the crop is in, and they return to their farms if permanent employment in the city is nor found. Should they be counted as unemployed? The extent of urban unemployment is also difficult to measure, since welfare in China is provided through the enterprise. Does a worker become unemployed when he is told to stay at home at one-half pay with housing and other benefits continued? Nonetheless, there is evidence that unemployment is rising in China, because the government is using it to an increasing degree to motivate economic development.

China's leadership has not been satisfied with the rates at which technological progress and the transfer of surplus workers to productive employment are taking place. The $15^{\text {th }}$ Party Congress which ended recently put his problem at centre stage, and measures were announced to transform or eliminate the unprofitable enterprises will be employed more intensively in the coming years, but it remains to be seen how much the radical restructuring of industry will take place through large scale bankruptcies and large-scale unemployment. The recent decline and collapse of the economies of many Asian countries has not had a material impact on employment in China, perhaps because China has strong controls on international capital movement. Consequently, it is possible that a higher rate of growth in productivity can he achieved without a massive increase in open unemployment.

A related problem that is gaining increased recognition and gradual solution is the development of an institutional structure that recognizes rights and obligations of the various stakeholders in state enterprises, including government in its role as government and as owner. It is well known in the West that the separation of ownership and control has forced stockholders to share enterprise profits with management in varying degrees. In fact, stockholders are expropriated to the degree that they lose control of the enterprise. China is still trying to find a solution to the problem of state ownership other than wholesale privatization, loss of control to enterprise managers or continued bureaucratic inefficient and paternalistic control by old line ministries.

China explores every possible option in the quest for modern technology. Western principles and institutions in management, education, government and other area of life are imported and experimented with in the same way as technology in industry is imported. See Guthrie (1998). Joint ventures and private enterprises have grown faster than state enterprises, and they lead the way in importing foreign technology. State enterprises are being transformed into 'limited liability' corporations, with shares being offered to private investors at home and abroad. However, these state corporations are not being privatized as in the West, where majority ownership and control are placed in private hands. The most significant growth in the private sector will be the continued integration of Hong Kong, Taiwanese and overseas capital into the Chinese economy. A substantial public sector did not put an end to capitalism in the countries of Western Europe, and a significant but relatively small private sector and private portfolio investment in state enterprises need not spell the end of market socialism. There is no evidence that China's leadership and people have an ideological commitment to socialism regardless of its cost. On 
the other hand, the experience of Russia, Eastern Europe, Southeast Asia and the other poor countries of the world is no reason to become integrated in the world capitalist order.

\section{CONCLUSION}

In aggregate, the prosperity of China's urban as well as its rural population is increasing at an impressive rate. Civil rights as well as human rights have also improved significantly over these years. Of course, China is still a poor country, and its people do not have the civil rights that exist in wealthy capitalist countries. Furthermore, the inequality of income, crime, prostitution and corruption that we find in capitalist countries have also increased considerably. However, their levels still do not approach what we observe in Indonesia, India, Mexico Egypt, Brazil, Russia, Ukraine and other large third and second world countries. Most important, China does not have the widespread grinding poverty and degradation, and the private and unofficial violence against the urban as well as the rural poor that exists in so many countries.

What is going on in China may, as some claim, be nothing more than a transition to capitalism, so that within 25 years it will be quite impossible to distinguish between China's economic system and the range of economic systems in which private ownership is predominant and the term welfare-corporate capital is appropriate. It is also possible that China and some other countries will find market socialism an attractive long-run alternative to welfare-corporate capitalism. Perhaps the differences between the two systems will become negligible over time, with both serving society well. That would be nice, but it cannot be taken for granted. China 's leadership seems convinced that both national independence and popular support require substantial progress over the next 25 years in per capita GNP and in consumption. What remains to be determined is whether the high growth rate needed to realize that objective requires: (1) the large-scale privatization involved in the transition to welfare-corporate capitalism; or (2) the continued ownership and control of the economy by government that is involved in the further development of market socialism.

\section{BIBLIOGRAPHY}

BARNET, R.J. and John CAVANAGH. 1994. Global Dreams: Imperial Corporations and the New World Order. New York: Simon a d Schuster.

BYRD, William A and Lin QINGSONG, eds. 1990. China's Rural Industry: Structure. Development and Reform. New York: Published for the World Bank (by) Oxford University Press.

CHANDLER. Alfred. 1990. Scale and Scope; the Dynamics of Industrial Capitalism. Cambridge, Mass: Harvard University Press.

CHANDLER. Alfred. 1977. The Visible Hand: The Managerial Revolution in American Business. Cambridge, Mass.: Harvard University Press. 
DANZINGER, Sheldon and Peter GOTTSCHALK. 1995. America Unequal. New York: Russel Sage Foundation; Cambridge, Mass.: Harvard University Press.

FELIX, David. 1998. "Asia and the Crisis of Financial Globalization” In Baker, D., G. Epstein, and R. Pollen, eds. Globalization and Progressive Economic Policy. New York: Cambridge University Press.

FINDLAY, Christopher, Andrew WATSON and Harry X. WU, eds. 1994. Rural Enterprises in China. New York: Sr. Martin's Press.

GALBRAITH, John Kenneth. 1967. The New Industrial State. Boston: Houghton Mifflin.

GORDON, David. 1 996. Fat and Mean. New York: Martin Kessler Books.

GORDON, Myron J. 1994. Finance Investment and Macroeconomics: The Neoclassical and Post Keynesian Solution. Aldershot, England: E. Elgar.

GORDON, Myron J. 1998. " Monopoly Power in the United States Manufacturing Sector, 1899 to 1994”. Journal of Post Keynesian Economics, 20(3), 313-35.

GORDON, Myron J., Yue LI, and Zhilong TIAN. 1998. "The Future of Market Socialism in China”, in Donald Brean, ed., Taxation in Modern China. New York and London: Routledge.

GRIFFIN, Keith and Renwei ZHAO, eds. 1993. The Distribution of Income in China. New York: St. Martin 's Press.

GUTHRIE, Doug. 1998. “The Declining Significance of Guanxi in China's Economic Transition”, The China Quarterly 154 (June) 254-82.

HARRISON, Bennett. 1994. Lean and Mean: The Changing Landscape of Corporate Power in the Age of Flexibility. New York: Basic Books.

HO, Samuel P. S. 1994. Rural China in Transition: Non-agricultural Development in Rural Jiangsu, 1978-1990. Oxford: Clarendon Press.

KAHN, A. R., and Carl RISKIN. 1998. "Income and Inequality in China; Composition, Distribution and Growth of Household Income, 1988 to 1995”, The China Quarterly 154 (June): 221-53.

KAHN, Jenifer. 1999. “The Green Machine”, Harper's 298 (April): 70-73.

KALECKI, M. 1954. Theory of Economic Dynamics. New York: Rinehart.

KORTEN, David C. 1995. When Corporations Rule the World. West Hartford CN: Kurmarin Press, and San Francisco: Bernett-Koehler.

MISHEL, Lawrence and J. BERNSTEIN. 1993. The State of Working America, 1992-3. Armouk N.Y.: M.E. Sharpe.

RIFKIN, Jeremy. 1995. The End of Work. New York: G.P. Putnam Sons.

ROZELLE, Scott. 1994. “ Decision-making in China's Rural Economy: the Linkage Between Village Leaders and Farm Households”, The China Quarterly 137 (March) 99-124.

SCHERER, Frederic and David ROSS. 1990. Industrial Market Structure and economic performance. $3^{\text {rd }}$. edition. Boston: Houghton Mifflin.

SCHUMPETER, Joseph A. 1942. Capitalism, Socialism and Democracy. New York: Harper and Row. SIMON, H. A. 1976. Administrative Behavior. 3rd edition. New York: Free Press.

WILLIAMSON, Oliver. 1985. The Economic Institutions of Capitalism. New York: Free Press.

WORLD BANK. 1997. Sharing Rising Incomes. Washington, D.C.: The World Bank. 